\title{
Why I Hate Wrestling (the Sport, Not the Foreplay!)
}

\section{DARRIN HAGEN}

$A$ version of this article by award-winning writer, composer, journalist, TV host, and all-around Queen Darrin Hagen was first published in the June 1999 (Pride) issue of Outlooks Newspaper under the title "Wrestling With A Double Standard. " It was originally written as a warm-up research exercise for Hagen's fringe-theater play PileDriver! Hagen reports, "The story caused quite a commotion ... it was linked to Xwrestling.com, which connects to all news about wrestling, and it received an astonishing - to me - 6,000 hits $a$ day. Then, Outlooks received a few nasty letters to the editor taking me to task for 'hetero-bashing', claiming theyas gay men - had been watching wrestling for years and had never seen anything like the stuff I mentioned. "Outlooks submitted the article to the Gay Press Association, where Hagen won second place in the Best Opinion / Editorial / News Analysis category in the regional division of the Vice Versa Awards. On his achievement, Hagen declares, "Caught me very much by surprise. I didn't even know I had been entered ... Wait, I should probably rephrase that!" Hagen's first book, The Edmonton Queen: Not a Riverboat Story, is in its second printing. His email address is edmontonqueen@hotmail.com.

When Tony Kushner's play Angels In America was produced in Alberta two seasons ago, the public outcry was enormous. Politicians stepped on each other to criticize a play that, even though it won the Pulitzer Prize, 'questioned the validity of a belief in God', promoted 
a homosexual, antifamily agenda, and featured more than one scene involving gay sexual situations. The Alberta Report featured a cover that had poster boy Mark Bellamy, dressed as a studly, buffed angel, covered in painted-on Kaposi's sarcoma. ${ }^{1}$ The right-wing called (again) for an end to arts funding (when the art in question reflects same-sex issues). When the dust cleared, Angels In America - Parts One and Two - outsold almost every other theatrical production in Edmonton and Calgary.

When singer and performer Marilyn Manson toured his dog and pony show through Alberta last year, the Calgary business community (fueled and encouraged by religious groups) canceled his one Cowtown performance, citing unsubstantiated rumors of onstage sacrifices, devil worship, and antestablishment lyrical content. The scandal was front-page news in Edmonton, where Manson played to far more people than he would have had the scandal in Cowtown not made him more notoriously infamous than he already was.

Two pieces of high-profile entertainment were challenged in this province strictly based on content (or rumors of that content). The amount of negative press Angels and Manson received was frightening: journalists wringing their hands in mock horror at the decay of our Albertan society.

The funny thing is, a show just traveled through both Calgary and Edmonton that featured onstage man/man sexual situations, an obsession with the Dark Forces, an open challenge to the authority of God, mock rape, and, dare I say it, necrophilia, symbolic dismemberment of women, nudity, foul language, and gasp! - really loud rock and roll. And it got nothing in the way of religious outcry, moralizing, or political comment.

Is Marilyn Manson starring in Angels In America? Is the Jim Rose Freak Circus back on the road?

No. Last Sunday I went to see WWF (the World Wrestling Federation).

I, three friends (my partner and a straight couple), and

${ }^{1}$ Mark Bellamy is the Calgary-based actor who posed for the Angels in America poster. Alberta Report used the photograph from the poster as the basis for its offensive cover. 


\section{$116 /$ Hagen}

thousands of screaming families converged on Edmonton's Skyreach Centre to watch Stone Cold Steve Austin, The Undertaker, The Brood, New Age Outlaws, Val Venus, Mankind and Golddust 'wrestle' in front of a sold-out crowd of children and ladies and gentlemen of all ages. Let me tell you, until you've heard eight-yearold girls screaming things like "Break his leg!" and "Finish him off!" you haven't really witnessed how low society can scrape.

First off, I have to say this: the show is actually quite entertaining, for about fifteen minutes. WWF shows have a lot more in common with the big annual Drag Ball than with any 'sporting' event. In fact, the reams of media coverage the WWF received while it was in the province (almost all positive, or, at least, tongue-in-cheek) was in the entertainment section of the newspaper. The 'show' consists of lots of introductions, lots of big entrances, lots of swaggering with an exaggerated sense of self-importance, lots of cheesy music cues, lots of larger-than-life personas, and the occasional prop. 'Titles' are read as the stars enter the room and stroll down a long ramp to their pounding music, a spotlight on them the whole way.

Once the actual 'wrestling' starts, it becomes even more like an overlong drag show: the numbers all start to sound and look the same after a while. Every match is almost identical in execution, utilizing the same pallet of moves and choreography, with occasional 'personality' variations. The Undertaker, for instance, generally relies on the pile driver move to stun his opponents into pretend unconsciousness. Val Venus enters to vampy burlesque sax music, wearing a towel, wiggling his derriere like a stripper at a stag party. The opponents generally insult each other, attacking such important topics as whose appendage is larger, the quality of a female partner's breasts, etc., until one is driven mad by the teasing and attacks. The audience cheers, then grows distracted as the 'fight' progresses. The success - entertainment-wise - of each match depends entirely on how skilled the performers are in making the violence look real. If I can tell from the nosebleed section of the Skyreach Centre that kicks or punches aren't connecting, I'm not going to care much about who wins. What keeps people watching is when the gimmicks start.

Every wrestler has a gimmick tied to their character's 
history or plot line. Al Snow carries a female mannequin head by the hair (AL: "What do we want?" CROWD: "Head!"). 'Head' talks to him and tells him who to take down. The Brood, consisting of pretty-boy heart-throb Edge and his also pretty Goth-vampire buddies Christian and Gangrelle, wear sexy pirate shirts and PVC pants, and flip their luxurious blond hair around more than a babe in a Bon Jovi video. Val Venus's striptease entrance relates to his history as a porn star. The New Age Outlaws (with Team De-Generation X) consist of Outlaw Jesse James (a.k.a. Road Dogg, "cause he likes it doggy-style") and Badass Billy Gunn (who likes flashing his bum to get the other team fightin' mad). Every time Jesse James gets a male opponent into a hard-to-get-out-of hold, he humps him from behind, or pretends to eat him out. The crowd goes wild at every sexual suggestion. Somehow, watching two boys having fake anal intercourse on stage is fine, as long as one of the men is being held in that position against his will. Or Jesse and Badass, in a perfectly choreographed oral gang rape, place two pseudounconscious opponents in opposing corners, then climb up on the ropes, pretend to fuck their faces, then pummel their heads with punches (all timed) while the audience counts the toll.

Of course, there are the women: Sable, Tori, Ivory, Jacqueline, all dressed for success in string bikinis, silver jumpsuits, and hair that flies around as they fight. Implant versus implant in this fight to the finish.

Who won? Does it matter? A half billion people (including three million Canadians) tune in each week to see the televised version of this road show. There is a recording studio being built to issue the release of WWF CDs, which are mostly "themed" collections of dinosaur heavy metal bands. There are theme hotels and amusement parks in the works. Stone Cold Steve Austin, the current smash fave (whose motto is on banners and t-shirts all over the Coliseum: "AUSTIN 3:16 Do Unto Others Before They Do Unto You"), is the merchandising king, selling 25,000 t-shirts a month. The ticket sales, the pay-per-view rights, the videos, the action figures all add up to an unstoppable commercial enterprise. Wrestling is huge business.

Supporters call it "a mock-violent soap opera that interacts with its crazed audience" and "escapist entertainment." And I 
suppose, on one level, that's true. The success of the WWF or of the tv show Jerry Springer prove that there is a rabid audience for the stuff that you can scrape out of the gutter. But when escapist entertainment is built on a bunch of thugs exhibiting Grade 8 locker room bullying, waving dicks in each other's faces to prove their masculinity, I have a problem with that. When an audience cheers they want 'Head' and they're talking about a symbolic decapitated female on stage, I have a problem with that. When the crowd goes wild while the New Age Outlaws pretend to assault the two men they just finished raping, the message is loud and clear: As long as you're the one doing the poking, you're not a fag. But make sure you beat up the fag you just fucked, so that you'll still be a man. People will cheer.

I have a serious problem with that.

And the worst part of all is that this sideshow is marketed mainly at children. I watched little boys and girls, supported by their parents, cheering the demasculinization of men who were held in positions in which they couldn't defend themselves against their rapists. As a gay man, I sat and listened as tens of thousands of people (mostly families) cheered simulated forced man-on-man anal sex and the subsequent beating of the victim.

Adults can watch what they want. But children all over the world are consuming this product. Forget the Backstreet Boys, The Spice Girls. When an ACCESS reporter asked a bunch of ten-year-old boys in Calgary what they wanted to see at the show, they screamed "We want to see the sluts!" In Edmonton, the hottest selling item at the merchandise stand was a baseball cap bearing the New Age Outlaws' motto: "SUCK IT!"

The media wasn't silent. Many are concerned with the effect wrestling has on the younger fans. But most of the press coverage the WWF received in Alberta was about its popularity. Not one journalist mentioned the homophobia or the sexism within the show. 'Everyone knows it's not real.' Yet when Angels in America was produced in Alberta, did the fact that everyone knows it's not real save it from being skewered as immoral? No. The image of two men in a gay relationship kissing was enough to draw fire from extremists all over the province. It was labeled as "perverted," or "anti-God." 
Where is the WWF headed? Is there any line it won't cross? Rumor has it that partial nudity (female, I assume) will play a big role. A little T\&A will send viewing figures through the stratosphere. But ultimately, the WWF and the hysteria that makes it so popular rely on one thing: the preservation of the myth of straight white male power. And in that context, it's perfectly correct. Its symbols of masculinity - brute force, fake violence, bravado, posturing, drawing your power from the disempowerment of others - are tried and traditional. It's a brilliant symbol of the last bastion of the old guard clinging to the tattered shreds of its former glory and power. That's why the claims of escapist entertainment are so disturbing. It's not escapist entertainment to the people who have to face that attitude in their lives on a daily basis. It's real. There's no escape. And there's nothing entertaining about it. 